\title{
Edukacja a „tło migracyjne” - europejskie doświadczenia i dylematy w drodze do integracji
}

\section{KEYWORDS}

migration crisis, integration by education, parallel societies, foreign pupils, European education

\begin{abstract}
Kapica-Curzytek Joanna, Edukacja a "tło migracyjne" - europejskie doświadczenia i dylematy w drodze do integracji [Education and migration - European experiences and dilemmas towards integration]. Kultura - Społeczeństwo Edukacja nr 1(13) 2018, Poznań 2018, pp. 105-116, Adam Mickiewicz University Press. ISSN 2300-0422. DOI 10.14746/kse.2018.13.8.
\end{abstract}

Poland is about to face social changes caused by a huge number of refugees and immigrants heading towards Europe. Not all of them come from societies whose culture is close to ours. The crisis of the peaceful idea of coexistence of cultures ((Multikulti) inspires us to analyse the European experience in the process of building integrated society and to draw conclusions. In this way we can avoid repeating some mistakes of other countries. In this situation, education must be a strong foundation of a state policy.

Kryzys migracyjny w Europie, który szczególnie przybrał na sile po roku 2015, osiągnął niespotykane dotąd rozmiary. Jego przyczyny - przede wszystkim natury ekonomicznej i politycznej - są złożone i wielowymiarowe. Wszystkie następstwa tego procesu są na razie jeszcze zbyt trudne do określenia i przewidzenia. Wiadomo z pewnością, że za sprawą imigrantów Europa od jakiegoś czasu doświadcza gruntownych zmian niemal we wszystkich sferach życia. Są to - i będą - także zmiany w systemach edukacji krajów Europy, które trzeba będzie dostosowywać do nowych wyzwań.

Także system oświaty w Polsce będzie musiał odnaleźć się w nowej europejskiej rzeczywistości społecznej. Jak dotąd panuje u nas jednak przekonanie, że Polskę kryzys migracyjny na razie omija, a problemy z nim związane nie dotyczą naszego 
kraju. Liczba uczniów innych narodowości uczęszczających do szkół w Polsce nie wydaje się jeszcze aż tak duża w porównaniu z krajami Europy Zachodniej. Poza uczniami, którzy zaliczają się do mniejszości etnicznych na pograniczach, polskie szkoły w całym kraju ciągle jeszcze mają do czynienia raczej z jednostkowymi przypadkami uczęszczania do nich osób o pochodzeniu innym niż polskie.

Należy jednak brać pod uwagę, że Polska stopniowo staje się miejscem z różnych powodów coraz atrakcyjniejszym dla imigrantów z różnych krajów i kręgów kulturowych - nawet jeśli nasz kraj jest dla nich na razie raczej przystankiem w dalszej drodze na zachód Europy. Szybciej niż na ogół się sądzi uczniowie cudzoziemcy pojawią się u nas w większej liczbie. Wtedy to polska szkoła stanie się w pełni tego słowa wielokulturowa i pojawią się w niej podobne problemy, jakich doświadczają inne państwa przyjmujące większą liczbę imigrantów. Zważywszy skalę imigracji do Europy - będzie to jedno z większych wyzwań stojących przed polskim systemem oświatowym po 1945 roku. Będą musieli mierzyć się z nim wszyscy, którzy zajmują się edukacją: nauczyciele, pedagodzy, terapeuci, doradcy.

W 2008 roku zauważano, że polscy nauczyciele na ogół byli pozostawieni sami sobie wobec obecności dzieci obcokrajowców w szkole. Musieli zdawać się na własną intuicję, wspieraną ewentualnymi doświadczeniami zdobytymi na innych obszarach działań pedagogicznych oraz na swoich kompetencjach interpersonalnych. Nie było żadnych narzędzi ani procedur, które pomogłyby radzić sobie w szkołach z tym nowym dla polskiej oświaty wyzwaniem (Stelmach, 2008: 82).

Na stronie Ministerstwa Edukacji Narodowej znajduje się zakładka: Nauka dzieci przybywajacych z zagranicy w polskim systemie edukacji. Są tu opublikowane ramy prawne, instrukcje i podstawowe informacje związane z nauką cudzoziemców w szkołach (m.in. dane liczbowe za rok szkolny 2018/2019), a nawet propozycje przydatnych materiałów, z których nauczyciele mogą korzystać podczas udzielania lekcji języka polskiego uczniom cudzoziemcom ${ }^{1}$.

Opublikowany w 2010 roku raport z badań Dzieci obcokrajowców w polskich placówkach oświatowych - perspektywa szkoły wykazuje „wzrastające zróżnicowanie kulturowej specyfiki uczniów” - czyli pojawianie się uczniów z „tłem migracyjnym”. W raporcie stwierdza się, że rozpoznanie tego zjawiska wpływa na wynikające z niego narastające problemy szkoły oraz wzmacnianie się u nauczycieli poczucia bezradności i niekompetencji. Jednocześnie zauważa się wzrastającą świadomość potrzeb związanych z dostosowaniem pracy polskiej szkoły i pozy-

${ }^{1}$ Ministerstwo Edukacji Narodowej. (2019). Nauka dzieci przybywających z zagranicy $w$ polskim systemie edukacji. https://www.gov.pl/web/edukacja/nauka-dzieci-przybywajacych-z-zagranicy-w-polskim-systemie-edukacji, dostęp: 15.04.2019. 
skiwaniem kompetencji umożliwiających efektywniejszą pracę z uczniami z „tłem migracyjnym” (Błeszyński, 2010: 9).

Coraz częściej dostrzega się zatem, że obecność obcokrajowców w szkole to zjawisko złożone i wymaga odmiennego podejścia niż praca z polskojęzycznymi uczniami. Trudności obcojęzycznych dzieci w posługiwaniu się językiem polskim to zaledwie wierzchołek góry lodowej. Przed nauczycielami i polskim systemem edukacji otwiera się nieznane dotąd oblicze wielowymiarowych, skomplikowanych problemów, wynikających z różnic kulturowych, religijnych, a także rasowych, które dotąd u nas były prawie nieobecne. Co więcej, obecność dzieci obcokrajowców w polskich szkołach jest słabo zakorzeniona w polskich realiach pedagogicznych i dlatego warto skorzystać z doświadczeń innych krajów.

Ostatnie lata przynoszą w tych państwach zmiany w spojrzeniu na samą integrację i ideę wielokulturowości. Heinz Buschkowsky, były burmistrz berlińskiej dzielnicy Neukölln, dzieli się spostrzeżeniem, że idea multikulti, wsparta źle pojętą polityczną poprawnością, idea tak zwanej pokojowej współobecności kultur i ich symbiozy - w założeniu prowadzącej do hybrydowych (przenikających się) form kultury - w Europie Zachodniej nie sprawdziła się (Buschkowsky, 2013: 71). W podobnym tonie wypowiedziała się kanclerz Niemiec Angela Merkel, oznajmiając, że „próby stworzenia w Niemczech społeczeństwa wielokulturowego zdecydowanie zawiodły” (Wróbel, 2010). O słabości ideologii multikulturalizmu, jako „tracącej wiarygodność”, wspomina także A. Szahaj (2010: 66). „Cechą wielokulturowości nie powinno być tolerowanie nietolerancji innej kultury”, podkreśla także Ayaan Hirsi Ali (2016: 37), imigrantka z Somalii, intelektualistka i znawczyni realiów islamu.

Integrację należy rozumieć jako proces długofalowy, obejmujący więcej niż tylko jedno pokolenie - tym bardziej, że nie wszyscy przybywają do Europy ze społeczności kulturowo jej bliskich. Integracja nowo przybyłych w dużej mierze zależy od kondycji edukacji - jakości systemu edukacyjnego i otwartości na problemy uczniów-cudzoziemców. Dlatego też system oświaty musi być pierwszym i najważniejszym filarem integracji. Gdy okaże się on niewydolny - pociąga to za sobą ogromne konsekwencje, nie tylko społeczne, ale i ekonomiczne. Heinz Buschkowsky zauważa, że „nic nie jest tak kosztowne jak jednostka niezintegrowana ze społeczeństwem" (Buschkowsky, 2013: 99)2 Wydatki na edukację nie mogą być zatem postrzegane jako niepotrzebne „generowanie kosztów”, ale jako niezbędna

\footnotetext{
2 Ten cytat i następne z tej książki - w tłumaczeniu własnym autorki artykułu.
} 
i niepodlegająca żadnej dyskusji inwestycja w jakość życia społecznego państwa oraz w jego spójność społeczną.

W Szwecji co trzeci uczeń z „łłem migracyjnym” nie kończy szkoły średniej, podczas gdy wśród rodowitych Szwedów naukę na tym szczeblu przerywa co piąty (Traub, 2016: 12). W 2011 roku tylko 22\% dzieci imigrantów w Niemczech zdało maturę, w porównaniu z 42\% dzieci rodowitych Niemców (Buschkowsky, 2013: 45). Te liczby będą z pewnością wyglądać inaczej, zważywszy wzrost populacji uchodźców w samych Niemczech o 126\% w 2015 roku w porównaniu z rokiem 2014 (Bloed, Masur, 2015: 37). Ale niezależnie od wszystkiego, za wszystkimi liczbami i statystykami kryją się złożone problemy, będące udziałem rodziców i opiekunów dzieci cudzoziemców. Dotyczą one najczęściej ich statusu społeczno-ekonomicznego, ujawnianych przez nich postaw, zdobytych doświadczeń, poglądów na życie i wyobrażeń o karierze. Są to problemy, z którymi musi mierzyć się system edukacji kraju-gospodarza.

Kreowanie modelu edukacji imigrantów to zadanie szczególnie trudne. Nie ulega wątpliwości, że najistotniejszą przyczyną trudności w integracji jest tak zwana luka edukacyjna. Przybywające do nowego kraju osoby przeważnie nie odebrały gruntownego wykształcenia w języku docelowym, a po przybyciu na miejsce - nie przejmują również żadnych elementów kultury ani norm społecznych obowiązujących w nowym kraju (por. Kelek, 2015: 94). O ile jeszcze dzieci i młodzież trafiają do szkół, luka ta rzadko jest niwelowana w przypadku osób dorosłych. Stale pozostają oni w sytuacji wykluczenia - mając kłopoty ze znalezieniem pracy, z mobilnością społeczną i nawiązywaniem kontaktów z kimkolwiek innym niż członkowie ich społeczności.

W rezultacie powstają tak zwane społeczeństwa równoległe (Parallelgesellschaften), nazywane także „koloniami etnicznymi” lub „społeczeństwami asymetrycznymi” (Buschkowsky, 2013: 62-63). Są to osobne, hermetyczne światy, z każdym dniem coraz bardziej się izolujące od większości społeczeństwa, nie ma w nich żadnych przejawów przenikania się, nawiązania dialogu czy prób wyjścia poza kulturowe granice. Budowane są natomiast sieci wewnętrznych powiązań, które służą temu, by pozostać między swoimi, przestrzegać własnych norm kulturowych i religijnych, osłaniać dzieci przed „szkodliwymi wpływami” - europejskim stylem życia i regułami społecznymi. Zjawisko to nazywa się "kokonizacją” (cocooning) (Hirsi Ali, 2016: 26).

Społeczeństwo równoległe charakteryzuje się tym, że cała jego energia jest kierowana w stronę utrzymania izolacji, by integrować się wyłącznie wewnętrznie i budować możliwie jak najbardziej ścisłe więzi z przedstawicielami swojej własnej grupy etnicznej i religijnej (Buschkowsky, 2013: 110). Jego członkowie „są obywa- 
telami krajów zachodnich, w których mieszkają, ale ich serca i umysły znajdują się gdzie indziej" (Hirsi Ali, 2015: 15). W skrajnych przypadkach izolacja jest tak daleko posunięta, że niektóre dzielnice europejskich miast wydają się wyjęte spod kontroli państwa; przykładem może być Molenbeek, dzielnica Brukseli, czy podparyskie przedmieście Saint-Denis.

Społeczeństwa równoległe utrwalają także, niestety, inne niepożądane zjawisko, z którym z trudem radzą sobie europejskie państwowe szkoły - dyskryminację na tle płci. W wielu rodzinach „z tłem migracyjnym” obowiązują odmienne modele wychowania chłopców i dziewcząt. Łączy się to przede wszystkim ze zróżnicowanym podejściem do wykształcenia. Szanse i perspektywy edukacyjne dla dziewcząt są znacznie ograniczane, a nawet odbierane - ze względu na tradycyjne podejście do roli kobiety w rodzinie. Skoro rodzice i tak zamierzają wydać córkę za mąż, gdy tylko skończy 16 lat, po co inwestować w jej wykształcenie i jaki jest sens, by przystępowała do matury czy planowała pójście na studia? Dziewczęta wychowywane są $\mathrm{w}$ - niewiarygodnej z punktu widzenia kryteriów zachodniej cywilizacji - uległości i posłuszeństwie, nie mogą wykazywać się samodzielnością ani niezależnością. Będąc stale poddane silnie zhierarchizowanej rodzinie i kontrolowane przez starszych mężczyzn, są w zasadzie po prostu ich własnością (Kelek, 2015: 25-26), w dosłownym znaczeniu tego słowa.

Próby nauczycieli, by mimo wszystko przełamywać ten model i wyrównywać dotkliwy brak aspiracji edukacyjnych, spotykają się ze stanowczym oporem rodziców: „Córka ma być dobrą żoną i matką, po co jej szkoła?”. Wartości demokratyczne, światopoglądowa otwartość i liberalizm - fundamenty europejskiej szkoły i systemu edukacji - stoją w wyraźnej opozycji wobec antydemokratycznych, archaicznych struktur spotykanych w domach rodzinnych wielu uczniów. Jest to konflikt cywilizacyjny, bowiem rodzice wywodzący się ze „społeczeństw równoległych" o rażąco niskim kapitale kulturowym nie przygotowują dzieci do nowoczesnej edukacji w nowoczesnym państwie (Hirsi Ali, 2015: 244). „Racjonalne, świeckie i indywidualistyczne wartości nowoczesności działają destrukcyjnie na tradycyjne społeczeństwa, zwłaszcza te, w których hierarchie opierają się na zależnościach płciowych i wiekowych oraz dziedziczeniu pozycji”, zauważa A. Hirsi Ali (2016: 25).

Dla dziewcząt wywodzących się ze „społeczeństw równoległych” nie do pomyślenia jest wybijanie się na niezależność myślenia i samodzielność w planowaniu własnej przyszłości, nie mówiąc już o karierze zawodowej. W tych rodzinach robi się wszystko, by je od tego odwieść (Buschkowsky, 2013: 111). W konsekwencji brak wykształcenia kobiet prowadzi do utrwalania luki edukacyjnej i powielania niskiego statusu socjokulturowego, który jest w dużej mierze główną przyczyną 
wzmacniania struktur „społeczeństw równoległych”. Niewykształcone matki nie są w stanie przygotować własnych dzieci do bycia odnoszącymi sukcesy obywatelami nowoczesnych, zachodnich społeczeństw (Hirsi Ali, 2015: 19). Pociąga to za sobą ogromne koszty - przestępczości, opieki społecznej, zasiłków itp. Badania niemieckie wykazują, że tylko co trzecie dziecko imigrantów wybija się na wyższy status socjokulturowy niż mieli ich rodzice (Bloed, Masur, 2015: 42). Problem ten dostrzega rząd holenderski, którego polityka wzmacniania wysiłków na rzecz integracji obejmuje - oprócz obowiązkowych kursów obywatelskich (języka i wiedzy o społeczeństwie) - także wspieranie emancypacji kobiet-imigrantek (Buschkowsky, 2013: 162).

Szkoły - jako baza i najsilniejszy filar procesu integracji - powinny dawać pozytywne wzorce oraz nadzieję na odmianę losu uczniom, a zwłaszcza uczennicom, wywodzącym się ze środowisk „ubóstwa edukacyjnego”. Z pewnością nie jest to łatwe zadanie dla pedagogów. Moja znajoma nauczycielka z Danii zwraca uwagę, że tamtejsi nauczyciele zatrudnieni w szkołach, do których uczęszczają uczniowie-obcokrajowcy, muszą koncentrować się na wielu innych rzeczach niż tylko na nauczaniu. $Z$ tego też powodu wielu duńskich rodziców przenosi swoje dzieci do innych szkół, jeżeli jest w nich zbyt dużo cudzoziemców, ponieważ poziom nauczania w takich placówkach znacząco się obniża.

W placówce, w której pracuje moja znajoma, dzieci cudzoziemców w klasach I-IV szkoły podstawowej mają dodatkowe lekcje języka duńskiego i kultury. Ponadto, w ramach studiów nauczycielskich jest przedmiot: „język duński dla dzieci z innego kręgu kulturowego", tak więc pedagodzy pracujący w szkole są świadomi problemów, które mogą w takich sytuacjach wystąpić. Ogromnym utrudnieniem jest jednak to, że w wielu obcojęzycznych rodzinach nie rozmawia się w domu po duńsku, a dzieci nie znają wielu najprostszych słów, nawet jeśli urodziły się w Danii. „Mam w swojej klasie uczennicę (...), która nie tylko z trudem uczy się duńskiej gramatyki, ale też frustruje ją to, że nie może bawić się po szkole z klasowymi koleżankami i kolegami. Dzieci takie jak ona są jakby 'złapane w pułapkę’ pomiędzy dwiema kulturami”, zauważa nauczycielka z Danii³.

Ostatnio często zwraca się uwagę, że szczególnym wyzwaniem dla europejskiego systemu edukacji może być tak zwane drugie pokolenie imigrantów. Mechanizm wygląda następująco: imigranci „pierwszego pokolenia” przybywający do nowego kraju na ogół są zajęci pracą i zapewnieniem rodzinie godziwych warunków życia. Sprawiają wrażenie, że nie stanowią zagrożenia dla wewnętrznego bezpieczeństwa krajów, w których mieszkają. Natomiast to drugie pokolenie,

\footnotetext{
${ }^{3}$ R. Lene Juel, prywatny list do autorki artykułu, czerwiec 2009.
} 
„Złapane w pułapkę”, jak opisaliśmy wcześniej, może doświadczać w szkole różnych form odrzucenia, jak zostało to opisane w powyższym liście. Młodzi ludzie są znacznie bardziej wyczuleni na dyskryminację i psychiczny dyskomfort związany z zaniżoną samooceną i poczuciem niskiej wartości. I jednocześnie mają dużo więcej czasu niż rodzice, by zajmować się pomysłami na życie, na przykład poszukiwaniem swojej „prawdziwej” tożsamości, w tym powrotem do kultury „korzeni”, którą opuściły ich rodziny (Strachota, Pięciak, 2015: 42). Tu tkwi bodaj najpoważniejsze zadanie dla europejskiego systemu edukacji: integrować, by zapobiegać radykalizacji, wygrywać walkę o „rząd dusz” i jeszcze lepiej edukować ludzi - nie tyle „wykorzenionych” z ich własnej kultury, ale szanujących i rozumiejących normy społeczne kraju, w którym mieszkają. A. Hirsi Ali podkreśla szczególnie palącą potrzebę edukacji obywatelskiej (Hirsi Ali, 2015: 274, zob. także: 277).

Jak zauważa H. Buschkowsky: „bez instytucji szkoły i solidnego kształcenia nie usunie się barier społecznych. To prawda znana nam już przecież od 150 lat" (Buschkowsky, 2013: 258). Aziz Al-Azmeh jest gorącym orędownikiem edukacji nakierowanej na integrację: „Jeśli pozwolimy zamkniętym wspólnotom na utrzymanie prymatu więzów krwi nad obywatelskością, to katastrofa będzie tylko kwestią czasu" (Rosiak, Al-Azmeh, 2015: 15). Również A. Hirsi Ali akcentuje wielkie znaczenie publicznej edukacji w procesie przezwyciężania „plemiennych” postaw, nastawionych na izolację i samowykluczenie (Hirsi Ali, 2015: 22).

Bardzo interesującym przykładem „usuwania barier”, o których mowa, jest znajdujący się w berlińskiej dzielnicy Neukölln kampus Rütli. W 2006 roku nauczyciele z tej szkoły napisali list otwarty do władz oświatowych z prośbą o jej zamknięcie ze względu na to, że nie potrafili już dłużej sobie radzić z wysokim poziomem przemocy i agresji wśród uczniów. W tamtym czasie 87\% uczniów miało inną narodowość niż niemiecka ${ }^{4}$. Zdecydowano się jednak szkoły nie zamykać, ale dofinansować i rozwinąć. Przekształcono ją po trzech latach w wielowymiarową przestrzeń społeczną. Znajduje się tutaj całodzienna szkoła ponadpodstawowa, żłobek, przedszkole, centrum spędzania wolnego czasu, klub młodzieżowy, centrum doradztwa zawodowego, ośrodek zdrowia, szkoła muzyczna i ludowa (ośrodek zajęć pozalekcyjnych) oraz miejsce zabaw. Zakończenie inwestycji, wynoszącej 35 mln euro, przewidziano na 2016 rok (Buschkowsky, 2013: 328). Nadal do szkoły uczęszcza prawie 90\% dzieci imigrantów, część z nich wywodzi się nawet z rodzin notowanych na policji (Buschkowsky, 2016: 274).

Kampus Rütli, wcześniej szkoła „z problemami”, obecnie - wzorcowa placówka, dzięki której można się przekonać, jak ważne jest inwestowanie w oświatę. To

\footnotetext{
${ }^{4}$ Rütli School. https://en.wikipedia.org/wiki/R\%C3\%BCtli_School, dostęp: 15.04.2019.
} 
dowód na to, że wydatki na edukację nigdy nie powinny być postrzegane jako „zło konieczne”, ale jako istotny element podnoszący jakość społecznego życia. Przestrzeń edukacyjna, w której miejsce dla siebie znajduje 20 tysięcy osób, to także próba nadania nowej formy i struktury dzielnicy Neukölln. Wcześniej był to obszar równie zamknięty i niebezpieczny jak brukselskie Molenbeek czy Saint-Denis, obecnie - optymistyczny symbol integracji poprzez edukację, na który spogląda cała Europa, obecnie uważany jest teraz nawet za modną artystyczną dzielnicę Berlina. Z tego przykładu płynie także wniosek, że nie wolno zasłaniać się „niemożnością” i wyrażać przekonania, że próby przezwyciężania barier w integracji na pewno się nie powiodą. W każdej sytuacji trzeba aktywnie działać, stale poszukując nowych sposobów dotarcia, rozwiązywania problemów, przezwyciężania barier. Edukacja to „bilet wyjścia” ze zgettoizowanego społeczeństwa równoległego (por. Tyszecka, 2016: 112).

Jednym $\mathrm{z}$ takich przykładów jest również szczególnie intensywnie rozwijany ostatnio w Niemczech projekt integracji dzieci z rodzin uchodźców poprzez sport ${ }^{5}$. Jego walory są nie do przecenienia. Uczestnictwo w sportowym programie - w atmosferze wspólnej zabawy - aktywizuje młodych ludzi, rozwija ich kompetencje społeczne, daje poczucie celu i sprawstwa. Nie bez znaczenia jest także rozwijanie kompetencji językowych. Dzieci i młodzież dużo łatwiej niż w klasie uczą się języka w sytuacjach nieformalnych - spontanicznie i niemal bez wysiłku. Wspólne uczestnictwo w zajęciach i imprezach sportowych prowadzi również do spotkań nowo przybyłych z gospodarzami: nie w atmosferze wrogości, podejrzliwości - ale w atmosferze zaufania, w poczuciu wspólnego celu. Uchodźcy i imigranci uczą się w ten sposób reguł świata gospodarzy, natomiast przyjmujący - uczą się pokonywać bariery w spotkaniach z nowo przybyłymi.

Edukacja musi także być skierowana w stronę członków społeczności przyjmującej imigrantów. Jednym z jej najważniejszych celów powinno być z pewnością przezwyciężanie strachu przed Überfremdungsangst, nadmiarem obcości w najbliższym otoczeniu. H. Buschkowsky definiuje to nie jako wrogość wobec konkretnych osób, co więcej - obawa ta nie bierze się nawet z powodu przeżycia jakiejś konkretnej sytuacji. To raczej atmosfera, klimat lęku, gdy ktoś zadaje sobie pytanie: „Gdzie jestem? Czy to jest jeszcze moje miasto? Mój kraj?” (Buschkowsky, 2013: 124-125). Odczucie to mogą ilustrować słowa P. Bieler z antyimigranckiej partii Szwedzkich Demokratów, wyrażające obawę, że „Szwecja utraci swoją tożsamość, poczucie, że mieszka się w społeczności, która jest także domem rodzinnym” (Traub, 2016: 12-13).

\footnotetext{
${ }^{5}$ Integracja przez sport i kształcenie. http://www.idsub.de/, dostęp: 15.04.2019.
} 
Lęk ten zdecydowanie da się - i trzeba - przezwyciężyć. Jeszcze przed wyborami burmistrza Londynu, na którego kandydował muzułmański polityk pochodzenia pakistańskiego Sadiq Khan, 30\% londyńczyków stwierdziło, że „czuliby się niekomfortowo z muzułmańskim burmistrzem” (Brytyjczycy sobie..., 2015: 37). Ale gdy został już wybrany, nie słychać negatywnych reakcji ${ }^{6}$, nie wyraża się obaw, że „obcy” może zaszkodzić rodzimej społeczności. Dla kreowania modelu edukacji warta zapamiętania jest przede wszystkim ta zależność: poziom lęku przed obcością znacznie spada, gdy rodzima społeczność ma już rzeczywiste i osobiste kontakty z „innymi”. Mogą o tym świadczyć na przykład wyniki wyborów w Niemczech: w landach, w których mieszka stosunkowo mało uchodźców, w ostatnich wyborach (wiosną 2016 roku) na tak zwane ugrupowania antyimigranckie głosował największy odsetek wyborców?

W perspektywie edukacji szkolnej, jak się okazuje, mechanizm wygląda bardzo podobnie. Krystyna Starczewska, wieloletnia dyrektorka Społecznego Liceum Ogólnokształcącego „Bednarska” w Warszawie, opowiada, że do szkoły są przyjmowani uchodźcy już od lat dziewięćdziesiątych XX wieku. Obecnie jedna piąta wszystkich uczniów w szkole to obcokrajowcy (imigranci i uchodźcy). To świadoma polityka szkoły, której zawsze zależało na tym, by placówka była otwarta na różnorodność. Uznano, że obecność w szkole uchodźców z różnych stron świata „będzie czymś w rodzaju pomocy naukowej dla (...) dzieci, dzięki ich obecności poznawać będą inne kultury, uczyć się tolerancji i akceptacji różnorodności” (Starczewska, Winnicka, 2015: 26-27). Wieloletnie praktyczne doświadczenia „Bednarskiej” (poparte przykładami przytaczanymi w wywiadzie) wskazują, że jest to jak najbardziej możliwe.

Szkoła ta, co prawda, obniżyła swoje notowania w rankingach (czego zawsze mocno obawiają się dyrektorzy), ale z wypowiedzi dyrektor Starczewskiej wynika, że nie to jest absolutnie najważniejszym kryterium jakości edukacji. Poza tym, jak wskazuje, można byłoby łatwo rozwiązać ten problem, nie wliczając do szkolnej średniej wyników uczniów, którzy są w Polsce krócej niż trzy lata, lub też zezwolić na wsparcie cudzoziemców na egzaminie: aby mogli mieć przy sobie słowniki, by mieć pewność, że dobrze rozumieją egzaminacyjne polecenia (Starczewska, Winnicka, 2015: 27).

${ }^{6}$ Wygrat po "gorzkiej i brutalnej walce". Światowe media o nowym burmistrzu Londynu. (2016). http://www.tvn24.pl/wiadomosci-ze-swiata,2/swiatowa-prasa-komentuje-wybor-nowego-burmistrza-londynu,641796.html, dostęp: 14.06.2016.

7 Abstimmungen in drei Ländern: Die Ergebnisse der Landtagswahlen im Überblick. (2016). http://www.spiegel.de/politik/deutschland/wahlen-2016-die-ergebnisse-der-landtagswahlen-im-ueberblick-a-1082093.html, dostęp: 14.06.2016. 
Doświadczenia zaprezentowane przez Krystynę Starczewską skłaniają nas ku przekonaniu, że obecność dzieci-obcokrajowców w klasie to szczególna forma edukacji interkulturowej. Przebiega ona w naturalnych warunkach, w codziennych, bezpośrednich kontaktach z przedstawicielami innych kultur i języków. Tak jak w realnym życiu, nie brakuje sytuacji trudnych, problemowych, które wymagają szczególnej umiejętności ich rozwiązywania.

Podsumowując, należy stwierdzić, że przed polskim systemem edukacyjnym stoi jeszcze wiele wyzwań dotyczących wypracowania procedur i działań związanych z przyjmowaniem do polskich szkół uczniów innych narodowości. Warto już teraz kształtować odpowiednie postrzeganie tych zagadnień i sięgać po doświadczenia innych krajów. Edukacja z uwzględnieniem „tła migracyjnego" powinna obejmować dwa przenikające się ze sobą nurty: musi być nie tylko skierowana w stronę nowo przybyłych, ale także dotyczyć społeczności przyjmujące imigrantów - osób, które obok nowo osiedlających się uczą się, mieszkają i pracują.

Najważniejszą osobą w tym procesie jest nauczyciel, którego rola kulturowego pośrednika polega na konieczności stworzenia korzystnych, pozbawionych negatywnych stereotypów i uprzedzeń warunków międzykulturowej komunikacji (Kapica-Curzytek, 2010: 99-101). Szkolna edukacja, często zbyt sformalizowana i nastawiona na uzyskiwanie jak najwyższych miejsc w rankingach edukacyjnych, musi dokładać starań, by promować postawy eliminujące stygmatyzację, ksenofobię, nietolerancję, etnocentryzm, agresję i rasizm.

Sądzimy, że nie trzeba na nowo formułować celów takiej edukacji: nadal aktualne są wyzwania, definiowane za pomocą tak zwanych czterech filarów edukacji, które wobec nowej rzeczywistości w szkołach nabierają szczególnego znaczenia:

- uczyć się, aby wiedzieć,

- uczyć się, aby działać,

- uczyć się, aby żyć wspólnie,

- uczyć się, aby być (Delors, 1998: 11).

Warto byłoby także rozważyć nadanie większego znaczenia edukacji europejskiej i obywatelskiej oraz wyraźniejsze akcentowanie celów: ukształtowania nowoczesnego, demokratycznego społeczeństwa sprawiedliwości i postępu, popartego bogactwem zróżnicowania kulturowego. Ogromną rolę odgrywa kształtowanie świadomości przynależności do wspólnoty i poczucia solidarności (Nikitorowicz, 2009: 237). Cele kształtują się tutaj co najmniej dwa: integracja nowo przybyłych, ale także przezwyciężanie nacjonalistycznych, skrajnie prawicowych i populistycznych postaw wśród społeczności gospodarzy. Ich źródłem jest eskalowany lęk, 
przeradzajacy się w agresję słowną, a nawet fizyczną. Jak zauważa brytyjski publicysta S. Kuper, jedynym kluczem do tego jest solidna edukacja (Kuper, 2012: 7).

Jerzy Nikitorowicz podkreśla, że „jesteśmy (...) na początku drogi europeizacji Europejczyków" (Nikitorowicz, 2009: 238), stąd trudno od razu spodziewać się widocznych rezultatów. Będą one widoczne najwcześniej po kilkudziesięciu latach. Podobnego czasu, by zmienić swój kształt, potrzebowała Europa ponad 70 lat temu, gdy kończyła się druga wojna światowa. Wtedy sytuacja była równie trudna, a może nawet jeszcze trudniejsza: kontynent był podzielony na dwa wrogie sobie obozy polityczne (strefy wpływów) oraz borykał się z trudnościami ekonomicznymi, koniecznością odbudowy infrastruktury z ruin oraz masowymi migracjami po drugiej wojnie światowej.

Warto zatem skupić się na celach działań edukacyjnych i pamiętać, że konsekwentne, długofalowe działania zawsze przyniosą efekty. Integracja europejska jest procesem - i to głównie od kondycji oświaty będzie zależało jej powodzenie. Bez edukacji nastawionej na wyraźnie nakreślone cele - nie będzie integracji, natomiast bez integracji - nie będzie dobrze funkcjonującej gospodarki ani spójnego, otwartego społeczeństwa, które jest fundamentem demokracji.

\section{Literatura}

Abstimmungen in drei Ländern: Die Ergebnisse der Landtagswahlen im Überblick. (2016). http://www. spiegel.de/politik/deutschland/wahlen-2016-die-ergebnisse-der-landtagswahlen-im-ueberblick-a-1082093.html, dostęp: 14.06.2016.

Bloed P., Masur J. (2015). Werden wir alle ärmer?. „Focus Money” nr 44, s. 36-43.

Błeszyński K.M. (2010). Dzieci obcokrajowców w polskich placówkach oświatowych - perspektywa szkoły. Raport z badań. Ośrodek Rozwoju Edukacji. Warszawa.

Brytyjczycy sobie, imigranci sobie. (2015). „Cooltura” nr 35, s. 37.

Buschkowsky H. (2013). Neukölln ist überall. Berlin.

Buschkowsky H. (2016). Die andere Gesellschaft. Berlin.

Delors J. (red.). (1988). Edukacja. Jest w niej ukryty skarb, Raport dla UNESCO, przeł. W. Rabczuk. Warszawa.

Hirsi Ali A. (2015). Nomadka, przeł. E. Krawczyk. Warszawa.

Hirsi Ali A. (2016). Heretyczka, przeł. J. Żuławnik. Warszawa.

Integracja przez sport $i$ wykształcenie. http://www.idsub.de/ dostęp: 15.04.2019.

Kapica-Curzytek J. (2010). Nauczyciel w szkole jako „culture broker” (pośrednik kulturowy) wobec uczniów obcokrajowców. „Kultura i Edukacja” nr 1, s. 95-107.

Kelek N. (2015). Chaos der Kulturen. Die Debatte um Islam und Integration. Köln.

Kuper S. (2012). How we can beat the far right. „Financial Times Magazine”, September 22-23, s. 7.

Ministerstwo Edukacji Narodowej, Nauka dzieci przybywajacych z zagranicy w polskim systemie edukacji (2018). https://www.gov.pl/web/edukacja/nauka-dzieci-przybywajacych-z-zagranicy-w-polskim-systemie-edukacji, dostęp 15.04.2019. 